\title{
Evaluation of the Efficacy of Colistin Therapy with or without Loading Dose in the Treatment of Multi Drug Resistant Gram-negative Bacterial Infections
}

\section{Çoklu İlaca Dirençli Gram-negatif Bakteriyel Enfeksiyonların Tedavisinde Yükleme Dozlu veya Yüklemesiz Kolistin Tedavisinin Etkinliğinin Değerlendirilmesi}

\author{
DEmine Kübra Dindar Demiray', @Şebnem Şenol Akar² \\ 'Bitlis State Hospital, Department of Infectious Diseases and Clinical Microbiology, Bitlis, Turkey \\ ${ }^{2}$ Celal Bayar University Hafsa Sultan Hospital, Department of Infectious Diseases and Clinical Microbiology, Manisa, Turkey
}

\begin{abstract}
Aim: Colistin (Col) is an agent used in the treatment of multidrugresistant gram-negative (MDRGN) bacterial infections. This drug has been administered with a loading dose in recent years to provide rapid clinical response and therapeutic blood levels. In our study, we aimed to evaluate whether there is a relationship between the efficacy of the loading dose of Col treatment, mortality, microbiological clearance during treatment, nephrotoxicity, and neurotoxicity side effects for the treatment of MDRGN bacterial infections.

Material and Method: In this retrospective study, which included a control group, 6-years data was analyzed. Totally, 323 patients who received Col treatment with or without loading dose (LD) were included in the study. Patients were divided into two groups; I: without Col-LD regimen (those who were hospitalized in 2011-2014), II: with Col-LD regimen (those who were hospitalized in 2015-2017). Demographic characteristics such as age, gender, microbiological cultures, laboratory results, side effects, and mortality of the patients were evaluated.

Results: A statistically significant relationship was found between with ColLD regimen and nephrotoxicity. However, it was determined that there was no statistically significant relationship between microbiological clearance without a Col-LD regimen. Nephrotoxicity was found to be decreased with the Col-LD regimen. Neurotoxicity was observed more frequently (3.7\%) in with Col-LD regimen. Initial and final C-reactive protein (CRP) and procalcitonin (PCT) levels were statistically significantly lower in with Col-LD regimen.

Conclusion: It was found that with Col-LD regimen had a statistically significant effect on nephrotoxicity, neurotoxicity, and treatment outcome, but had no effect on microbiological clearance. In addition, with Col-LD regimen was effective in decreasing CRP and PCT values.
\end{abstract}

Keywords: Colistin, colistin loading therapy, multiple resistant, gram negative bacterial infection.
Öz

Amaç: Kolistin (Col), çok ilaca dirençli gram-negatif (MDRGN) bakteriyel enfeksiyonların tedavisinde kullanılan bir ajandır. Bu ilaç hızlı klinik yanıt ve terapötik kan seviyeleri sağlamak için son yıllarda yükleme dozu ile uygulanmaktadır. Çalışmamızda MDRGN bakteriyel enfeksiyonlarının tedavisinde Col tedavisinin yükleme dozunun etkinliği ile mortalite, tedavi sırasındaki mikrobiyolojik klirens, nefrotoksisite ve nörotoksisite yan etkileri arasında bir ilişki olup olmadığını değerlendirmeyi amaçladık.

Gereç ve Yöntem: Kontrol grubu içeren bu retrospektif çalı̧mada 6 yıllık veriler analiz edildi. Toplamda yükleme dozu (LD) olan veya olmayan Col tedavisi alan 323 hasta çalışmaya dahil edildi. Hastalar iki gruba ayrıldı; I: Col-LD rejimi almayanlar (2011-2014'te hastaneye yatırılanlar), II: Col-LD rejimi uygulananlar (2015-2017'de hastaneye yatırılanlar). Hastaların yaş, cinsiyet, mikrobiyolojik kültürler, laboratuvar sonuçları, yan etkiler ve mortalite gibi demografik özellikleri değerlendirildi.

Bulgular: Col-LD rejimi ile nefrotoksisite arasında istatistiksel olarak anlamlı bir ilişki bulundu. Ancak Col-LD rejimi olmadan mikrobiyolojik klirens arasında istatistiksel olarak anlamlı bir ilişki olmadığı belirlendi. Col-LD rejimi ile nefrotoksisitenin azaldığı bulundu. Nörotoksisite, Col-LD rejiminde daha sık (\%3.7) gözlendi. Illk ve son C-reaktif protein (CRP) ve prokalsitonin (PCT) seviyeleri Col-LD rejiminde istatistiksel olarak anlamlı derecede düşüktü.

Sonuç: Col-LD rejiminin nefrotoksisite, nörotoksisite ve tedavi sonucu üzerinde istatistiksel olarak anlamlı bir etkiye sahip olduğu, ancak mikrobiyolojik klirens üzerinde hiçbir etkisinin olmadığı bulundu. Ayrıca Col-LD rejimi ile CRP ve PCT değerlerinin düşürülmesinde etkili olmuştur.

Anahtar Kelimeler: Kolistin, kolistin yükleme tedavisi, çoklu dirençli, gram negatif bakteriyel enfeksiyon.

Corresponding (İletişim): Emine Kübra Dindar Demiray, Bitlis State Hospital, Department of Infectious Diseases and Clinical Microbiology, Bitlis, Turkey

E-mail (E-posta): e.kubradindar@hotmail.com

Received (Geliş Tarihi): 19.01.2022 Accepted (Kabul Tarihi): 26.01.2022 


\section{INTRODUCTION}

The antimicrobial resistance of Gram-negative (GN) bacteria is globally threatening. The United States (USA) Center for Disease Control and Prevention (CDC) reported that amongst multidrug-resistant (MDR) GN, extended-spectrum betalactamase (ESBL) organisms, carbapenemase-producing Enterobacteriaceae, carbapenem-resistant Acinetobacter species, multi-resistant Pseudomonas aeruginosa are emerging and spreading globally. ${ }^{[1]}$ Infections caused by MDR GN bacteria are among the main causes of mortality, especially for critically ill patients hospitalized in intensive care units (ICUs). ${ }^{[2]}$ In addition, these infections are associated with increased healthcare costs and length of hospital stay. ${ }^{[1]}$

Colistin, also called polymyxin E, was used clinically in the late 1950s, but was shelved in the early 1970s due to its nephrotoxicity and neurotoxicity side effects and the presence of less toxic antibiotics. ${ }^{[3]}$ Since there were no new antibiotics at a level to respond to the increasing antibiotic resistance, colistin was accepted as a last-resort treatment option. ${ }^{[4]}$ On the other hand, the increasing use of colistin has resulted in the increasingly widespread use of colistin resistance worldwide, and the increasing trend of resistance rates has gradually reduced the treatment options of clinicians. ${ }^{[5]}$

The low post-antibiotic effect of colistin may cause unsuccessful clinical response and development of resistant subpopulations in critically ill patients due to insufficient dose $^{[6]}$ In addition to providing therapeutic blood levels, the rapid and effective clinical response has been recommended to be given with a loading dose of colistin in recent years. ${ }^{[6,7]}$ For these reasons, it has been reported that there is a higher clinical success with the loading dose, and no significant change is found in terms of side effects. ${ }^{[6,8]}$

This study aimed to evaluate whether there is a relationship between the efficacy of the loading dose of colistin treatment, mortality, microbiological clearance during treatment, nephrotoxicity, and neurotoxicity side effects for the treatment of MDRGN bacterial infections. And also, to reveal whether there is a change between reactive protein (CRP) and procalcitonin (PCT) levels were aimed.

\section{MATERIAL AND METHOD}

\section{Study Design and Patients}

In our retrospective study, which included a control group, 6-years data was analyzed. Since colistin treatment was given without loading before the year 2015 in our hospital, no additional intervention was made to differentiate the groups. Totally, 323 patients who received colistin treatment with a loading dose (LD) or without LD, were included in the study. Patients were divided into two groups; I: without ColLD regimen (those who were hospitalized in 2011-2014), II: with Col-LD regimen (those who were hospitalized in 20152017). Demographic characteristics such as age, gender, microbiological cultures, laboratory results, side effects, and mortality of the patients were evaluated.
In those who did not take the loading dose, colistin was used intravenously (IV) $150 \mathrm{mg}$ every 12 hours. In patients who received a loading dose; $300 \mathrm{mg}$ colistin was administered as a maintenance dose of $150 \mathrm{mg} 12$ hours after IV loading dose, then 150 mg every 12 hours.

\section{Definations}

Microbiological clearance was defined as the absence of the same type of bacterial growth or control culture negativity which was taken after the 3rd and 7th days of colistin treatment. The clinical response was defined as a decrease in CRP and PCT values at the beginning and end of treatment.

RIFLE (Risk-Injury-Failure-Loss-Endstage) scoring (8) was used for nephrotoxicity determination. For neurotoxicity, it was accepted that neurotoxicity developed in patients who were evaluated as drug-induced neurotoxicity after neurology consultation due to symptoms during hospitalization.

\section{Data Collection and Microbial Identification}

The data of patients who received colistin therapy were retrospectively scanned on the Probel Patient Information Management System program. Demographic characteristics such as age, gender, microbiological cultures, laboratory results, side effects, and mortality of the patients were evaluated. Microbiological cultures were studied with the VITEC 2 Compact 15 ( bioMérieux ) device in the microbiology laboratory of our hospital and verified by E-test when necessary.

\section{Statistical Analysis}

IBM SPSS Statistics for Windows (v21.0; IBM Corp) program was used to analyze the data. After testing the frequency analysis, firstly, a normal distribution test was performed for all variables. Cross-tabular descriptive statistics analysis was performed to determine the composition of possible subgroups resulting from the variables within the whole. The Chi-square (Chi-Square) test was used to find the explanatory power of the independent variable on the dependent variables, and the Wilcoxon test, which is a Two-Related Sample Test, was used to determine the relationship between the variables. The Wilcoxon test was used to check whether there is a significant difference between the observed values of the two covariates that are related to each other. Variables, mean standard error, categorical variables were given as numbers or $\%$. In all statistical comparisons, $p \leq 0,05$ values were considered statistically significant.

The study was conducted in accordance with the approval of Manisa Celal Bayar University Faculty of Medicine Clinical Research Ethics Committee (Date: 04.06.2016, Decision No: 32).

\section{RESULTS}

Totally, 323 patients, 123 (67.9\%) of with LD regimen, 93 (65.5\%) of the patients were without Col-LD regimen, were included in the study. 216 of them (66.9\%) were male and the average age of the patients in the study group was $62.21 \pm 19.28,112$ (61.8\%) of with Col-LD regimen and 84 (59.2\%) of the group without Col-LD regimen were over 65 years old. 
When the homogeneity of the variances of the group distributions is evaluated with the $F$ Levene's test for both subgroups of the study in terms of age, gender and accompanying risk factors, underlying diseases; It was observed that age, gender, and presence of diabetes were homogeneous in both groups ( $p>0.05$ ). It was observed that there was no homogeneity between other dimensions such as neurological disorder, hematological malignancy, previously antibiotic usage, presence of a peripheral catheter, and mechanical ventilation $(p<0.05)$ (Table 1).

\begin{tabular}{lccl} 
Table 1. Homogeneity test of variances. & $\begin{array}{c}\text { With Col-LD } \\
(\mathbf{n = 1 8 1})\end{array}$ & $\begin{array}{c}\text { Without Col-LD } \\
(\mathbf{n = 1 4 2})\end{array}$ & $\mathbf{p}$ \\
\hline Variable & 123 & 93 & .721 \\
\hline Gender (M) & 58 & 49 & .364 \\
Gender(F) & 112 & 84 & .628 \\
$>65$ years & 33 & 21 & .251 \\
Diabetes mellitus & 36 & 50 & .002 \\
Neurological disorder & 26 & 6 & .002 \\
Hematological malignancy & 29 & 20 & .374 \\
Solid organ malignancy & 168 & 141 & .004 \\
Previously antibiotic usage & 168 & 142 & .000 \\
presence of peripheral catheter & 95 & 99 & .001 \\
\hline Presence of mechanical ventilation & 95
\end{tabular}

In the evaluation of a total of 323 patients included in the study according to their department; the majority of the patients (39.9\%) were hospitalized in the Anesthesia Intensive Care Unit (ICU). The other clinics where the patients are hospitalized are surgical ICU $(7.7 \%)$, internal medicine ICU $(17 \%)$, hematology $(4 \%)$, infectious diseases (1.5\%), oncology $(0.6 \%)$, other (Plastic surgery, Orthopedics) Cardiology, etc.) wards (29.1\%). The most common reasons for using colistin therapy were NP / VAP (Nosocomial pneumonia / ventilatorassociated pneumonia) (48.9\%) and sepsis (25\%). 99 (30.7\%) of the patients who received colistin therapy had colistin monotherapy. It was found that 168 of them (52.0\%) received their treatment in combination with at least one antibiotic. It was found that double or triple antibiotic combination therapy was used in 56 (17.3\%) patients.

To examine the relationship between Col- LD regimen and mortality, a bivariate Chi-Square test (Chi-Square independence test) was used. The chi-square test value was found to be $4.944(p=0.04)$. Since the $p$-value was less than 0.05 at the $95 \%$ confidence interval, a significant relationship was found between Col- LD regimen and mortality (Table 2 ).

A Chi-square test was used to examine the relationship between with Col-LD regimen and nephrotoxicity. According to the analysis results, the Chi-square value was calculated as 15,256 and the $p$-value was calculated as 0,000 , and a statistically significant relationship was found between colistin loading and nephrotoxicity (Table 3 ). Nephrotoxicity was less common in the Col-LD regimen. The relationship between colistin loading and neurotoxicity was found to be significant as the type $(p=0.011)$ (Table 4).
Table 2. Evaluation the relationship between mortality and colistin loading dose regimen.

\begin{tabular}{|c|c|c|c|c|}
\hline & & $\begin{array}{c}\text { Non } \\
\text { survivors }\end{array}$ & Survivors & Total \\
\hline \multirow{6}{*}{ 옹 } & existing & 103 & 78 & 181 \\
\hline & $\%$ Among those Col LD & $56.9 \%$ & $43.1 \%$ & $100.0 \%$ \\
\hline & Total \% & $31.9 \%$ & $24.2 \%$ & $56.0 \%$ \\
\hline & existing & 92 & 50 & 142 \\
\hline & $\%$ Among those Col LD & $64.8 \%$ & $35.2 \%$ & $100.0 \%$ \\
\hline & Total \% & $28.5 \%$ & $15.4 \%$ & $44.0 \%$ \\
\hline & existing & 195 & 128 & 323 \\
\hline \multirow[t]{2}{*}{ Total } & $\%$ Among those Col LD & $60.4 \%$ & $39.6 \%$ & $100.0 \%$ \\
\hline & Total \% & $60.4 \%$ & $39.6 \%$ & $100.0 \%$ \\
\hline
\end{tabular}

\begin{tabular}{lccc}
\hline & $\begin{array}{c}\text { Chi-Square test } \\
\text { Value }\end{array}$ & Sd & $\begin{array}{c}\text { Full Significance } \\
\text { (2 tails) }\end{array}$ \\
\hline Pearson Chi-Square & $4.944^{\mathrm{a}}$ & 2 & .004 \\
Probability Ratio & 5.241 & 2 & .007 \\
Linear Relationship & .907 & 1 & .041 \\
\hline
\end{tabular}

a0 cells $(0,0 \%)$ have expected count less than 5 . The minimum expected count is $9,67,{ }^{*} \mathrm{Chi}$-Square test

Table 3. Evaluation of the relationship between colistin loading dose, nephrotoxicity and neurotoxicity.

\begin{tabular}{|c|c|c|c|c|c|c|c|}
\hline & \multicolumn{2}{|c|}{ nephrotoxicity } & \multirow{2}{*}{ Total } \\
\hline & & & & & yes & no & \\
\hline \multirow{11}{*}{ 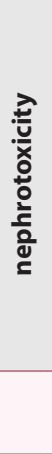 } & \multirow{7}{*}{$\frac{9}{\frac{1}{0}}$} & \multirow{3}{*}{$\stackrel{5}{3}$} & \multicolumn{2}{|l|}{ existing } & 79 & 102 & 181 \\
\hline & & & \multicolumn{2}{|c|}{$\%$ Among those Col LD } & $43.6 \%$ & $56.4 \%$ & $100.0 \%$ \\
\hline & & & \multicolumn{2}{|c|}{ Total \% } & $24.5 \%$ & $31.6 \%$ & $56.0 \%$ \\
\hline & & 苛 & \multicolumn{2}{|l|}{ existing } & 93 & 49 & 142 \\
\hline & & $\stackrel{ }{\geq}$ & \multicolumn{2}{|c|}{$\%$ Among those Col LD } & $65.5 \%$ & $34.5 \%$ & $100.0 \%$ \\
\hline & & & \multicolumn{2}{|c|}{ Total \% } & $28.8 \%$ & $15.2 \%$ & $44.0 \%$ \\
\hline & & & \multicolumn{2}{|l|}{ existing } & 172 & 151 & 323 \\
\hline & \multirow{2}{*}{\multicolumn{2}{|c|}{ Total }} & \multicolumn{2}{|c|}{$\%$ Among those Col LD } & $53.3 \%$ & $46.7 \%$ & $100.0 \%$ \\
\hline & & & \multicolumn{2}{|c|}{ Total \% } & $53.3 \%$ & $46.7 \%$ & $100.0 \%$ \\
\hline & & & & & \multicolumn{2}{|c|}{ neurotoxicity } & \multirow{2}{*}{ Total } \\
\hline & & & & & yes & no & \\
\hline \multirow{7}{*}{\multicolumn{2}{|c|}{ 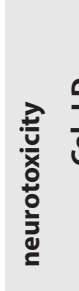 }} & \multirow{3}{*}{ 紊 } & \multicolumn{2}{|l|}{ existing } & 11 & 170 & 181 \\
\hline & & & \multirow{2}{*}{\multicolumn{2}{|c|}{$\begin{array}{l}\% \text { Among those Col LD } \\
\text { Total \% }\end{array}$}} & $6.1 \%$ & $93.9 \%$ & $100 \%$ \\
\hline & & & & & $3.4 \%$ & $52.6 \%$ & $56.0 \%$ \\
\hline & & $\stackrel{\Perp}{3}$ & \multicolumn{2}{|c|}{ existing } & 1 & 141 & 142 \\
\hline & & $\stackrel{\circ}{£}$ & \multirow{2}{*}{\multicolumn{2}{|c|}{$\begin{array}{l}\% \text { Among those Col LD } \\
\text { Total \% }\end{array}$}} & $0.7 \%$ & $99.3 \%$ & $100.0 \%$ \\
\hline & & $\xi$ & & & $0.3 \%$ & $43.7 \%$ & $44.0 \%$ \\
\hline & & & \multicolumn{2}{|l|}{ existing } & 12 & 311 & 323 \\
\hline \multirow{2}{*}{\multicolumn{3}{|c|}{ Total }} & \multicolumn{2}{|c|}{$\%$ Among those Col LD } & $3.7 \%$ & $96.3 \%$ & $100.0 \%$ \\
\hline & & & \multicolumn{2}{|c|}{ Total \% } & $3.7 \%$ & $96.3 \%$ & $100.0 \%$ \\
\hline \multicolumn{8}{|c|}{ Chi-Square test } \\
\hline & & & & Value & Sd & \multicolumn{2}{|c|}{$\begin{array}{l}\text { Full Significance } \\
\text { ( } 2 \text { tails) }\end{array}$} \\
\hline \multicolumn{4}{|c|}{ Pearson Chi-Square } & $6,422^{a}$ & 1 & \multicolumn{2}{|c|}{.011} \\
\hline & Prob & pabili & ity Ratio & 5,008 & 1 & & \\
\hline & Line & $\operatorname{ar} \operatorname{Re}$ & elationship & 7,739 & 1 & & \\
\hline
\end{tabular}

There was no statistically significant relationship between colistin loading and microbiological clerance $(p=0,393)$ (Table 4). 


\begin{tabular}{|c|c|c|c|c|c|}
\hline & & & \multicolumn{2}{|c|}{ Col LD } & \multirow{2}{*}{ Total } \\
\hline & & & without & with & \\
\hline \multirow{8}{*}{ 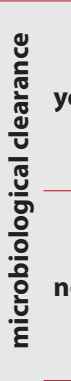 } & \multicolumn{2}{|l|}{ existing } & 68 & 60 & 128 \\
\hline & \multicolumn{2}{|c|}{ Expected value } & 71.7 & 56.3 & 128.0 \\
\hline & \multicolumn{2}{|c|}{$\begin{array}{l}\text { among microbiological } \\
\text { clearance existed \% }\end{array}$} & $53.1 \%$ & $46.9 \%$ & $100.0 \%$ \\
\hline & \multicolumn{2}{|c|}{$\%$ Among those Col LD } & $37.6 \%$ & $42.3 \%$ & $39.6 \%$ \\
\hline & \multicolumn{2}{|c|}{ Gözlenen Değer } & 113 & 82 & 195 \\
\hline & \multicolumn{2}{|c|}{ Expected value } & 109.3 & 85.7 & 195.0 \\
\hline & \multicolumn{2}{|c|}{$\begin{array}{l}\text { among microbiological } \\
\text { clearance existed \% }\end{array}$} & $57.9 \%$ & $42.1 \%$ & $100.0 \%$ \\
\hline & \multicolumn{2}{|c|}{$\%$ Among those Col LD } & $62.4 \%$ & $57.7 \%$ & $60.4 \%$ \\
\hline \multirow{4}{*}{ Total } & \multicolumn{2}{|c|}{ existing } & 181 & 142 & 323 \\
\hline & \multicolumn{2}{|c|}{ Expected value } & 181.0 & 142.0 & 323.0 \\
\hline & \multicolumn{2}{|c|}{$\begin{array}{l}\text { among microbiological } \\
\text { clearance existed \% }\end{array}$} & $56.0 \%$ & $44.0 \%$ & $100.0 \%$ \\
\hline & \multicolumn{2}{|c|}{$\%$ Among those Col LD } & $100.0 \%$ & $100.0 \%$ & $100.0 \%$ \\
\hline \multicolumn{6}{|c|}{ Chi-Square Test } \\
\hline & & Value & Sd & \multicolumn{2}{|c|}{$\begin{array}{l}\text { Full Significance } \\
\qquad(2 \text { tails) }\end{array}$} \\
\hline \multicolumn{2}{|c|}{ Pearson Chi-Square } & $.730^{\mathrm{a}}$ & 1 & \multicolumn{2}{|c|}{.393} \\
\hline \multicolumn{2}{|c|}{ Probability Ratio } & .547 & 1 & \multicolumn{2}{|c|}{.459} \\
\hline \multicolumn{2}{|c|}{ Linear Relationship } & .729 & 1 & \multicolumn{2}{|c|}{.393} \\
\hline
\end{tabular}

The Wilcoxon test is used to check whether there is a significant difference between the observed values of two covariates that are related to each other. In this study, the nonparametric Wilcoxon test was used to investigate whether there was a difference between the first and last CRP PCT values of patients loaded with colistin. The first and last C-reactive protein (CRP) values of 177 out of 323 patients (100 from those who were loaded and 77 from those who did not) could be reached in the study. In the evaluation of the difference between the first and last CRPs of the patients who were loaded with colistin, the mean of the first CRP was 41.83 and the standard deviation was 67.82. The average the last CRP of the patients who were loaded with colistin was 30.98 , and the standard deviation was 48.62. As can be seen, there is a decrease in the CRP of the same patients with colistin loading. These findings show that the difference between the first CRP and the last CRP is significant at the $95 \%$ confidence interval $(Z=-2.077, p<0.05)$. The average of the first CRP of the evaluation of the difference between the first and last CRPs of the patients without colistin loading is 31.61, the standard deviation is 39.39. The average the last CRP of the patients who cannot be loaded with colistin is 29.22 , and the standard deviation is 36.02 . As can be seen, there is a very low decrease in CRP of patients who are not loaded with colistin. However, these findings showed that the difference between CRP at the beginning of treatment and CRP at the end of treatment was not significant $(Z=-1.953, p=0.06)$. In other words, while there was a great decrease in the CRP of the patients who were loaded with colistin, the decrease in the CRP of the patients who were not loaded was evaluated as significant. This shows that colistin loading has a high level of effect on CRP.

\begin{tabular}{|c|c|c|c|c|c|c|c|}
\hline & & Results & $\mathbf{n}$ & mean & sd & $\mathbf{Z}$ & $\mathbf{P}$ \\
\hline \multirow{4}{*}{$\stackrel{\circ}{\text { 똔 }}$} & \multirow{2}{*}{ With } & First CRP & 100 & 41,83 & 67,82 & \multirow{2}{*}{$-2,077$} & \multirow{2}{*}{0,03} \\
\hline & & Last CRP & 100 & 30,98 & 48,62 & & \\
\hline & \multirow{2}{*}{ Without } & İlk CRP & 77 & 31,61 & 39,39 & \multirow{2}{*}{$-1,953$} & \multirow{2}{*}{0,06} \\
\hline & & Last CRP & 77 & 29,22 & 36,02 & & \\
\hline \multirow{4}{*}{ 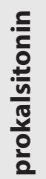 } & \multirow{2}{*}{ With } & First PCT & 49 & 15,52 & 27,82 & \multirow{2}{*}{$-3,492$} & \multirow{2}{*}{0,00} \\
\hline & & Last PCT & 49 & 5,90 & 17,63 & & \\
\hline & \multirow{2}{*}{ Without } & First PCT & 51 & 31,61 & 24,82 & \multirow{2}{*}{,- 682} & \multirow{2}{*}{0,49} \\
\hline & & Last PCT & 51 & 26,22 & 21,76 & & \\
\hline
\end{tabular}

\begin{tabular}{lccc}
\hline & \multicolumn{3}{c}{ Chi-Square Test } \\
& Value & Sd & $\begin{array}{c}\text { Full Significance } \\
\text { (2 tails) }\end{array}$ \\
\hline Pearson Chi-Square & $15,256^{\mathrm{a}}$ & 1 &, 000 \\
Probability Ratio & 14,391 & 1 &, 000 \\
Linear Relationship & 15,425 & 1 &, 000 \\
\hline $\begin{array}{l}\text { a } 0 \text { cells }(0,0 \%) \text { have expected count than } 5 \text {. The minimum expected count is } 66,38 \\
\text { * sd: standard deviation, CRP: C reactive protein. }\end{array}$ \\
\hline
\end{tabular}

The first and last PCT values of a total of 100 patients, 49 of whom were taken as a sample in the study, and 51 of whom were not loaded with colistin, were reached. In the evaluation of the difference between the first and last PCT of the patients who were loaded with colistin, the mean of the first PCT was 15.52 and the standard deviation was 27.82. The mean of the final PCT of the same patients is 5.90 , the standard deviation is 17.63. As can be seen, a significant decrease is observed in the PCT of the same patients with colistin loading. It is seen that the difference between the first PCT and the last PCT of these patients is significant at a $95 \%$ confidence interval $(Z=-$ $3.492, p<0.05)$. The mean of the first PCT of the evaluation of the difference between the first and last PCTs of the patients without colistin loading is 31.61 and the standard deviation is 24.82. The average of the last PCT of the patients who cannot be loaded with colistin is 28.22 , and the standard deviation is 22.76. As can be seen, although there is a decrease in the PCT of patients without colistin loading, it is seen that the difference between PCT at the beginning of treatment and $\mathrm{PCT}$ at the end of treatment is not statistically significant $(\mathrm{Z}=-$ $1.953, p>0.05)$.

\section{DISCUSSION}

In the GN bacterial infections that develop in hospitalized patients; since Enterobacteria (especially Klebsiella spp. and Escherichia coli), Pseudomonas aeruginosa, and Acinetobacter baumannii are frequently encountered as causative agents and they can develop resistance, colistin continues to be one of the limited number of antibiotics we have. ${ }^{[9]}$ Usage and doses of colistin may differ from country to country. The main reason for this is the existence of different formulations in the market and the dosage of some products using milligrams $(\mathrm{mg})$ and others using international unit (IU) units. This situation may cause a difficult understanding of the pharmacokinetic and pharmacodynamic properties of colistin. Therefore, as new researches and studies are conducted, the colistin dose is 
revised. It can be seen that this situation delays compliance with new dose recommendations and even causes different dosing administrations even in the same hospital. The optimal dose of colistin has not been defined. Although there are small descriptive studies evaluating the loading dose of colistin, very few of them included a control group. Because colistin is an old drug; It has not been developed with modern drug development procedures, and data to guide its use are limited. ${ }^{[10,11]}$

It has been hypothesized that the colistin loading dose is an improvement in treatment. ${ }^{[12]}$ In the Sanford Antimicrobial Treatment Guideline published in November 2012, it was stated that colistin initially increased the efficacy of $5 \mathrm{mg} / \mathrm{kg}$ loading dose. ${ }^{[12,13]}$ Recent guidelines recommend an IV loading dose of $300 \mathrm{mg}$ of colistin base activity followed by a daily. ${ }^{[14]}$ maintenance dose of $2 \mathrm{mg} / \mathrm{mg}$ target plasma concentration adjusted according to renal function However, it has been reported that more evidence is needed regarding the risks and benefits of the loading dose, and strategies are urgently needed. ${ }^{[10,11,15]}$ In our hospital, colistin has been used with a loading dose since 2015.

Nazer et al. ${ }^{[1]]}$ reported that there are no randomized controlled studies among the clinical studies evaluating colistin, only two studies by Trifi ${ }^{[16]}$ and Elefritz ${ }^{[17]}$ were the control group. Also in the same review; It has been reported that there are only 3 studies on the pharmacokinetics of colistin..$^{[3,10,18]}$

Pharmacokinetic modeling showed that the loading dose reduced the time to reach therapeutic concentrations in patients with infections due to CD-GN pathogens; however, clinical data on this dosing approach are limited. ${ }^{[3,19]}$

In the literature, it is stated that an important risk factor for the development of colistin resistance is the long-term use of colistin, but there is no clear information about the duration. As the most effective strategy to prevent colistin resistance formation, the use of colistin in combination with other antimicrobials has been recommended. ${ }^{[20]}$ In our study, 99 (30.7\%) of the patients used only colistin, while 168 (52.0\%) received their treatment in combination with an antibiotic. The double or triple antibiotic combination was administered to $56(17.3 \%)$ patients.

Meropenem was mostly used in the combination. Our patients with colistin resistance also received combined therapy. Because, in addition to reducing colistin resistance, combination therapies are recommended to increase the clinical efficacy of colistin. ${ }^{[21]}$ One of the important reasons why colistin is preferred in combination therapy is that although the microorganism is only sensitive to colistin, the partial destruction of the bacterial cell wall as a result of the use of carbapenem and the increase in colistin activity on the cell membrane over time. ${ }^{[22]}$ Studies have been conducted on its combined use with a carbapenem, tigecycline, sulbactam, and colistin, and it has been shown that combined therapy is more effective. ${ }^{[20]}$ In our study, colistin monotherapy was found to be homogeneous in both groups. Abdelsalam et al. ${ }^{[23]}$ reported that the combination of meropenem-colistin caused a significant decrease in mortality compared to cases where colistin was used alone; the association of combination therapy with significant hepatoxicity, nephrotoxicity, and neurotoxicity has not been established. In our study, no significant difference was found between colistin monotherapy and combination therapy in terms of clinical, biochemical response, and mortality side effects.

One concern with using the loading dose regimen of colistin is its potential for nephrotoxicity. Colistin-associated nephrotoxicity rates range from $6 \%$ to $48 \% .{ }^{[19,24]}$ Colistinrelated nephrotoxicity is usually mild and returns to normal when the drug is discontinued. Most cases of nephrotoxicity shown in this study are mild and reversible. Patients receiving colistin therapy with hypertension or chronic kidney disease should be closely monitored and the administration of neurotoxic agents should be avoided in all patients whenever possible. $^{[25]}$

Pogue et al. ${ }^{[26]}$ retrospectively evaluated risk factors for the development of colistin-related nephrotoxicity using RIFLE criteria and reported that ARF developed in $43 \%$ of the patients, and ARF developed depending on the dose of colistin. Independent risk factors in multivariate analysis are; simultaneous use of rifampicinand concomitantadministration of 3 or more nephrotoxic agents. Although Doshi et al. ${ }^{[27]}$ had a 6.5 times higher risk of nephrotoxicity in critically ill patients who received at least 2 nephrotoxic agents, no relationship was found between total daily dose or total cumulative IV colistin dose and nephrotoxicity. Similarly, Elefritz et al. ${ }^{[17]}$ reported that ARF developed in $50 \%$ of the patients in the preapplication period and $58 \%(\mathrm{p}=0.59)$ in the post-application period, and there was no statistical difference. However, in the same study; it was thought that the nephrotoxicity rates were higher than previously reported in both groups, but this result was determined because only critically ill patients were evaluated in this study ${ }^{[17]}$ Katip et al. ${ }^{[27]}$ in the prospective cohort study; 102 cancer patients diagnosed with multiple resistant A.baumanii infections were evaluated. In this study; 75 patients were given a loading dose of colistin; There was no significant clinical and microbiological response in patients in the loading dose group or patients in the unloading dose group. However, nephrotoxicity according to RIFLE criteria developed in 38 (50.67\%) patients in the loading dose group and $6(22.22 \%)$ patients in the unloaded dose group ( $p=0.013)$. Independent predictors of nephrotoxicity were reported as colistin administration with a loading dose and age $>60$ years. Alp et al. ${ }^{[15]}$ in their half experimental study; MDR A. baumannii infected ventilator-associated pneumonia patients who received and did not receive Col LD were compared. For those who take the loading dose; on the 14th day of treatment, the clinical improvement rate increased from $47.6 \%$ to $56.7 \%$, but bacteriological clearance ( $80 \%$ versus $81 \%)$, ICU mortality $(50 \%$ versus 54.2\%), or the duration of stay in the ICU ( median: 32 versus 36 days) found no significant difference. It was found 
that mortality increased in patients with nephrotoxicity and age was the only risk factor for nephrotoxicity. Also; overall, he reported that nephrotoxicity was more severe in those receiving the loading dose according to the RIFLE criteria. Bellos et al. ${ }^{[28]}$ eight (three prospective and five retrospective cohorts) studies consisting of 1115 patients were included in the meta-analysis study. In this study; it has been reported that administration of colistin loading dose does not change the clinical, treatment response, mortality, or nephrotoxicity risk (28). In our study; it was found that nephrotoxicity decreased with the LD $(p=0.000)$.

The most common side effects of colistin therapy are nephrotoxicity and neurotoxicity. Although there are numerous case reports of nephrotoxicity, little literature information is available on the neurotoxicity of the drug. There are limited reports, especially on psychiatric side effects. ${ }^{[29-32]}$ Dai et al. ${ }^{[33]}$ reported that colistin administration (15 mg/kg/day for 7 days) can cause significant mitochondrial dysfunction in central and peripheral nerve tissues. In our study, neurotoxicity was observed more frequently $(3.7 \%)$ in patients who received a loading dose of colistin. Since we only see neurotoxicity in 12 of all patients in total, it is thought that it will not be statistically significant to evaluate this statistically. In other studies, no data related to these were found.

Grégoire et al. ${ }^{[34]}$ reported that colistin loading dose is associated with less exposure to subtherapeutic colistin concentration, thus limiting the emergence of bacterial resistance. Trifi et al. ${ }^{[16]}$ reported that, the Col LD group had a higher maintenance dose than the group without Col LD, and it is difficult to evaluate the clinical treatment response in this study. In another study, no significant difference was found between patients with and without colistin loading. [16] In a study conducted on 30 patients with MDR-associated VIP infection, clinical and microbiological usefulness was not found. ${ }^{[15]}$ Bellos et al. ${ }^{[28]}$ reported that administration of Col LD was associated with higher microbiological response rates, especially in $A$. baumannii infections. Katip et al. ${ }^{[27]}$ reported that there was no statistically significant clinical and microbiological difference between the patients in the loading dose group or the patients in the non-loading dose group. Also; In multivariate logistic regression analysis, it has been reported that the presence of septic shock is associated with both a poor clinical and microbiological response, rather than the application of colistin. ${ }^{[27]}$ In our study; in terms of microbiological response, there was no significant relationship with colistin loading.

In the available literature; data on the relationship between colistin loading dose and CRP and PCT could not be reached. In our study, the decrease in CRP values above was found to be statistically significant between patients with and without colistin loading, whose initial and final CRP values could be reached. However, there was a very low decrease in CRP value without colistin loading and it was not statistically significant. Also again between the two groups; The written PCT value is given to the patient decreases and a significant decrease was not observed in the absence of loading.

\section{CONCLUSION}

Colistin loading therapy; It was found that its effect on nephrotoxicity, neurotoxicity and treatment outcome was statistically significant $(95 \% \mathrm{Cl}, \mathrm{p}<0.05)$, but it had no effect on microbiological response. In addition, when the loading dose of colistin therapy was compared with the load-free treatment; It was found to be effective in decreasing CRP and PCT values. There is a need for randomized controlled studies involving more patients evaluating colistin loading therapy.

Limitations of the study: Only the patient data belonging to our own hospital were evaluated retrospectively, so the number of cases is insufficient.

\section{ETHICAL DECLARATIONS}

Ethics Committee Approval: The study was conducted in accordance with the approval of Manisa Celal Bayar University Faculty of Medicine Clinical Research Ethics Committee (Date: 04.06.2016, Decision No: 32).

Informed Consent: Because the study was designed retrospectively, no written informed consent form was obtained from patients.

Referee Evaluation Process: Externally peer-reviewed.

Conflict of Interest Statement: The authors have no conflicts of interest to declare.

Financial Disclosure: The authors declared that this study has received no financial support.

Author Contributions: All of the authors declare that they have all participated in the design, execution, and analysis of the paper, and that they have approved the final version.

Note: This article has been written based on the corresponding author's post doctoral thesis.

\section{REFERENCES}

1. Aydın M, Azak E, Bilgin $\mathrm{H}$, et al. Changes in antimicrobial resistance and outcomes of health careassociated infections. Eur J Clin Microbiol Infect Dis 2021. doi:10.1007/s10096-020-04140-y.

2. LaPlante K, Cusumano J, Tillotson G. Colistin for the treatment of multidrug-resistant infections. Lancet Infect Dis 2018;18(11):1174-5.

3. Mohamed AF, Karaiskos I, Plachouras D, et al. Application of a loading dose of colistin methanesulfonate in critically ill patients:population pharmacokinetics, protein binding, and prediction of bacterial kill. Antimicrob Agents Chemother 2012;56(8):4241-9.

4. Shorr AF. Review of studies of the impact on Gram-negative bacterial resistance on outcomes in the intensive care unit. Crit Care Med 2009;37(4):1463-9.

5. Tüzemen NÜ, Efe K, Akalın H, Özakın C. Retrospective evaluation of colistin-resistant isolates in automated system by gradient diffusion method and broth microdilution method. Klimik Derg 2019;32(1):57-61.

6. Magiorakos AP, Srinivasan A, Carey RB, et al. Multidrug-resistant, extensively drug-resistant and pandrug-resistant bacteria:an international expert proposal for interim standard definitions for acquired resistance. Clin Microbiol Infect 2012;18(3):268-81.

7. Landersdorfer CB, Nation RL. Colistin: how should it be dosed for the critically ill? Semin Respir Crit Care Med 2015;36(1):126-35. 
8. Rocco M, Montini L, Alessandri E, et al. Risk factors for acute kidney injury in critically ill patients receiving high intravenous doses of colistin methanesulfonate and/or other nephrotoxic antibiotics:a retrospective cohort study. Crit Care 2013;17:R174.

9. Çetin Ç, Türk D, Şenol Ş, Horasan G, Tünger Ö. Colistin efficacy in the treatment of multidrug-resistant and extremelydrug-resistant gramnegative bacterial infections. Turk J Med Sci 2016;46(5):1379-84.

10. Grégoire N, Mimoz O, Mégarbane B, et al. New colistin population pharmacokinetic data in critically ill patients suggesting an alternative loading dose rationale. Antimicrob Agents Chemother 2014;58(12):7324-30.

11. Nazer LH, Anabtawi N. Optimizing colistin dosing:Is a loading dose necessary? Am J Health Syst Pharm 2017;74(1):e9-e16.

12. The Sanford Guide to Antimicrobial Therapy 2012. In:Gilbert DN, Moellering RC, Eliopoulos GM, Chambers HE, Saag MS (eds). 42nd ed.

13. Yemişen M, Özaras R. Kolistin. FLORA 2011;16(Ek 3):15-26.

14. Tsuji BT, Pogue JM, Zavascki AP, et al. International Consensus Guidelines for the Optimal Use of the Polymyxins:Endorsed by the American College of Clinical Pharmacy (ACCP), European Society of Clinical Microbiology and Infectious Diseases (ESCMID), Infectious Diseases Society of America (IDSA), International Society for Anti-infective Pharmacology (ISAP), Society of Critical Care Medicine (SCCM), and Society of Infectious Diseases Pharmacists (SIDP). Pharmacotherapy 2019;39(1):10-39.

15. Alp E, Eren E, Elay G, Cevahir F, Esmaoğlu A, Rello J. Efficacy of loading dose of colistin in Acinetobacter baumannii ventilator-associatedpneumonia. Infez Med 2017;25(4):311-9.

16. Trifi A, Abdellatif S, Daly F, et al. Efficacy and Toxicity of High-Dose Colistin in Multidrug-Resistant Gram-Negative Bacilli Infections:A Comparative Study of a Matched Series. Chemotherapy 2016;61(4):190-6.

17. Elefritz JL, Bauer KA, Jones C, Mangino JE, Porter K, Murphy CV. Efficacy and Safety of a Colistin Loading Dose, High-Dose Maintenance Regimen in Critically III Patients With Multidrug-Resistant Gram-Negative Pneumonia. J Intensive Care Med 2017;32(8):487-93.

18. Karaiskos I, Friberg LE, Pontikis K, et al. Colistin Population Pharmacokinetics after Application of a Loading Dose of 9 MU Colistin Methanesulfonate in Critically III Patients. Antimicrob Agents Chemother 2015;59(12):7240-8.

19. Vicari G, Bauer SR, Neuner EA, Lam, SW. Association between colistin dose and microbiologic outcomes in patients with multi-drug resistant gramnegative bacteremia. Clin Infect Dis. 2013;56(3):398-404.

20. Cai Y, Chai D, Wang R, Liang B, Bai N. Colistin resistance of Acinetobacter baumannii:clinical reports, mechanisms and antimicrobial strategies. J Antimicrob Chemother 2012 Jul;67(7):1607-15.

21. Akalın H. Kolistin, ANKEM dergisi 2007;21(Ek 2):26-28.

22. Nation RL, Li J, Cars O, et al. Framework for optimisation of the clinical use of colistin and polymyxin B:the Prato polymyxin consensus. Lancet Infect Dis 2015;15(2):225-34.

23. Abdelsalam MFA, Abdalla MS, El-Abhar HSE. Prospective, comparative clinical study between high-dose colistin monotherapy and colistinmeropenem combination therapy for treatment of hospital-acquired pneumonia and ventilator-associated pneumonia caused by multidrugresistant Klebsiella pneumoniae. J Glob Antimicrob Resist 2018;15:127-35.

24. Rocco M, Montini L, Alessandri E, et al. Risk factors for acute kidney injury in critically ill patients receiving high intravenous doses of colistin methanesulfonate and/or other nephrotoxic antibiotics:a retrospective cohort study. Crit Care 2013;17(4):R174.

25. Doshi NM, Mount KL, Murphy CV. Nephrotoxicity associated with intravenous colistin in critically ill patients. Pharmacotherapy 2011;31(12):1257-64.

26. Pogue JM, Lee J, Marchaim D, et al. Incidence of and risk factors for colistin-associated nephrotoxicity in a large academic health system. Clin Infect Dis 2011;53(9):879-84.

27. Katip W, Uitrakul S, Oberdorfer P. Clinical outcomes and nephrotoxicity of colistin loading dose for treatment of extensively drug-resistant Acinetobacter baumannii in cancer patients. Infect Drug Resist 2017;10:293-8

28. Bellos I, Pergialiotis V, Frountzas M, Kontzoglou K, Daskalakis G, PerreaDN. Efficacy and safety of colistin loading dose:a meta-analysis. J Antimicrob Chemother 2020;75(7):1689-98.
29. Nigam A, Kumari A, Jain R, Batra S. Colistin neurotoxicity:revisited. BMJ Case Rep 2015;2015:bcr2015210787.

30. Myint T, Evans ME, Burgess DR, Greenberg RN. Respiratory Muscle Paralysis Associated With Colistin, Polymyxin B, and Muscle Relaxants Drugs:A Case Report. J Investig Med High Impact Case Rep 2016;4(1):2324709616638362.

31. Lindesmith LA, Baines RD, Jr, Bigelow DB, Petty TL. Reversible respiratory paralysis associated with polymyxin therapy. Ann Intern Med. 1968;68:318-27.

32. Velkov T, Dai C, Ciccotosto GD, Cappai R, Hoyer D, Li J. Polymyxins for CNS infections:Pharmacology and neurotoxicity. Pharmacol Ther 2018;181:8590.

33. Dai C, Li J, Li J. New insight in colistin induced neurotoxicity with the mitochondrial dysfunction in mice central nervous tissues. Exp Toxicol Pathol 2013;65(6):941-8.

34. Grégoire N, Aranzana-Climent V, Magréault S, Marchand S, Couet W. Clinical Pharmacokinetics and Pharmacodynamics of Colistin. Clin Pharmacokinet 2017;56(12):1441-60. 